Situs Jurnal : $\underline{\text { http://ejurnal.stiepancasetia.ac.id/index.php/jieb }}$

Jilid 4 Nomor 2 Juli 2018

Hal 176 - 190

\title{
MINAT SISWA SMK MELANJUTKAN STUDI KE PERGURUAN TINGGI PADA SISWA KELAS XII JURUSAN AKUNTANSI SMK DHARMA PUTERA BANJARMASIN
}

\section{Reksa Setiawan*}

Abstract: Business in education is essentially a system to produce a qualified human beings in accordance with national educational goals that are expected to play an important role in national development. This study aims to determine the reasons for students to continue their education to universities so that universities can determine the appropriate learning system to support these interests. The research was conducted descriptively quantitatively through the distribution frequency with the respondents of all students of Accounting Class XII in SMK Dharma Putera Banjarmasin totaled 30 people. The results of the analysis found that the interest of students to continue their education to higher education is caused by internal factors, especially the desire to get a job with a good career.

Keywords: student's interest, vocational high school, higher education

Abstrak: Usaha pendidikan pada hakekatnya merupakan suatu sistem untuk menghasilkan manusia yang berkualitas sesuai dengan tujuan pendidikan nasional yang di harapkan dapat berperan penting dalam pembangunan nasional. Penelitian ini bertujuan untuk mengetahui alasan siswa SMK untuk melanjutkan pendidikannya ke perguruan tinggi sehingga perguruan tinggi bisa menentukan sistem pembelajaran yang tepat untuk mendukung minat tersebut. Penelitian dilakukan secara deskriptif kuantitatif melalui distribusi frekuensi dengan responden seluruh siswa Jurusan Akuntansi kelas XII di SMK Dharma Putera Banjarmasin sejumlah 30 orang. Hasil analisis menemukan bahwa minat siswa untuk melanjutkan pendidikannya ke perguruan tinggi lebih besar disebabkan oleh factor yang bersifat internal, terutama sekali keinginan untuk mendapatkan pekerjaan dengan karir yang baik.

Kata kunci : minat siswa, SMK, perguruan tinggi

\section{Latar Belakang}

Pendidikan merupakan aspek penting bagi perkembangan sumber daya manusia, sebab pendidikan merupakan wahana atau salah satu instrumen yang di gunakan bukan saja untuk membebaskan manusia dari keterbelakangan, melainkan juga dari kebodohan dan kemiskinan. Pendidikan di yakini mampu menanamkan kapasitas baru bagi semua orang untuk mempelajari pengetahuan dan keterampilan baru sehingga dapat di peroleh manusia produktif. Di sisi lain, pendidikan di percayai sebagai wahana perluasan akses.

Melalui pendidikanlah seseorang dapat memperoleh ilmu pengetahuan yang mereka butuhkan baik melalui pendidikan formal maupun non formal. Maka sewajarnya apabila pemerintah dan semua pihak memberikan perhatian yang besar terhadap pendidikan karena bagaimanapun juga pendidikan turut menentukan perkembangan dan kelangsungan kehidupan bangsa. Undang-undang No. 20, tahun 2003. Pasal 3 menyebutkan : "Pendidikan nasional berfungsi mengembangkan kemampuan dan membentuk watak serta peradaban bangsa yang 
bermanfaat dalam rangka mencerdaskan kehidupan bangsa, bertujuan untuk berkembangnya potensi peserta didik agar menjadi manusia yang beriman dan bertakwa kepada Tuhan Yang Maha Esa, berakhlak mulia, sehat, berilmu, cakap, kreatif, mandiri, dan menjadi warga negara yang demokratis serta bertanggung jawab."

Berpijak dari pengertian tersebut, usaha pendidikan pada hakekatnya merupakan suatu sistem untuk menghasilkan manusia yang berkualitas sesuai dengan tujuan pendidikan nasional yang di harapkan dapat berperan penting dalam pembangunan nasional.

Pendidikan, sebagaimana yang tercantum pada UU RI No. 20 Tahun 2003 tentang sistem pendidikan nasional, diartikan sebagai usaha sadar dan terencana untuk mewujudkan suasana belajar dan proses pembelajaran agar peserta didik secara aktif dapat mengembangkan potensi dirinya untuk memiliki kekuatan spiritual keagamaan, pengendalian diri, kepribadian, kecerdasan, akhlak mulia, serta keterampilan yang di perlukan dirinya, masyarakat, bangsa dan negara.

Melalui pendidikan di harapkan dapat membentuk manusia Indonesia yang menguasai ilmu pengetahuan dan teknologi yang di butukan bagi peningkatan kesejahteraan, kemajuan peradaban, serta ketangguhan daya saing yang sejajar dengan bangsa lain.

Pendidikan merupakan suatu proses yang harus di selenggarakan secara terus menerus sampai kapanpun, karena apabila pendidikan tidak di selenggarakan, maka kemajuan masyarakat akan terhenti, bahkan dapat mundur. Oleh karena itu pendidikan harus di selenggarakan secara terpadu antara pemerintah, masyarakat, dan keluarga. Seperti yang kita ketahui bahwa pendidikan itu berlangsung seumur hidup dan di laksanakan dalam lingkungan keluarga, masyarakat, dan sekolah. Ini berarti manusia mempunyai tanggung jawab untuk belajar sejak di lahirkan sampai meninggal dunia. Dengan asas belajar sepanjang hayat di harapkan setiap individu mempunyai kesadaran mau membelajarkan dirinya karena pendidikan yang berupa ilmu pengetahuan dan teknologi merupakan kebutuhan yang harus di penuhi dalam kehidupannya.

Pendidikan di Indonesia di laksanakan baik secara formal, non formal, dan informal. Jenjang pendidikan formal terdiri atas pendidikan dasar, pendidikan menengah dan pendidikan tinggi. Pendidikan dasar adalah pendidikan umum yang lamanya sembilan tahun, di selenggarakan enam tahun di Sekolah Dasar dan tiga tahun di Sekolah Menengah Pertama, Pendidikan dasar bertujuan untuk memberikan bekal kemampuan dasar kepada peserta didik untuk mengembangkan kemampuannya sebagai pribadi, anggota masyarakat, warga negara, dan anggota manusia serta mempersiapkan peserta didik untuk mengikuti pendidikan menengah.

Pendidikan menengah adalah pendidikan yang di selenggarakan selama tiga tahun yang bertujuan untuk melanjutkan dan meluaskan pendidikan dasar serta mempersiapkan peserta didik menjadi anggota masyarakat yang memiliki kemampuan mengadakan hubungan timbal balik dengan lingkungan sosial, budaya, dan alam sekitar serta dapat mengembangkan kemampuan lebih lanjut dalam memasuki dunia kerja maupun pendidikan selanjutnya yaitu pendidikan tinggi. Pendidikan menengah ini terdiri atas pendidikan menengah atas (SMA), dan pendidikan menengah kejuruan (SMK).

Jenjang pendidikan selanjutnya adalah pendidikan tinggi dengan segala bentuk penyelenggaraanya. Pendidikan tinggi bertujuan untuk mempersiapkan peserta didik yang memiliki kemampuan akademis maupun kemampuan profesional yang dapat menerapkan, mengembangkan dan menciptakan ilmu pengetahuan dan teknologi. Sehingga dari pendidikan tinggi akan lahir ahli-ahli yang dapat berperan sebagai pelaku, pelaksana sekaligus penemu hal-hal yang dapat bermanfaat bagi kehidupan masyarakat.

Sekolah Menengah Kejuruan (SMK) merupakan jenjang pendidikan menengah yang mengutamakan pengembangan keterampilan peserta didik untuk melaksanakan jenis pekerjaan tertentu. Sekolah Menengah Kejuruan bertujuan untuk mempersiapkan siswa agar 
memiliki keterampilan dan siap terjun ke dunia kerja. SMK di golongkan menjadi enam kelompok antara lain kelompok Pertanian dan Kehutanan, kelompok Teknologi dan Industri, kelompok Kesahteraan Masyarakat, Kelompok Pariwisata, Kelompok Seni dan Kerajinan.

Sekolah Menengah Kejuruan (SMK) mempunyai perbedaan yang sangat menonjol dengan Sekolahan Menengah Atas (SMA). SMK lebih menitik beratkan pada penguasaan keterampilan praktis sebagai bekal untuk memasuki dunia kerja. Sedangkan SMA lebih menekankan pada penguasaan ilmu pengetahuan cenderung teoritis sebagai bekal untuk melanjutkan pendidikan yang lebih tinggi. Dalam hal program pendidikan, di SMK pelajaran praktik mendapat porsi yang lebih besar dari pada pelajaran teori, sedangkan SMA sebaliknya.

Dari uraian tersebut dapat di rumuskan bahwa SMK mempunyai tujuan utama menghasilkan lulusan yang siap kerja, sedangkan SMA bertujuan menghasilkan lulusan untuk melanjutkan pendidikan yang lebih tinggi. Sehingga dalam hal keterampilan bekerja, siswa SMK akan jauh lebih unggul karena telah memiliki bekal keterampilan untuk terjun ke dunia kerja. Tetapi dalam hal studi lanjut, siswa SMK kemungkinan akan kalah bersaing dengan siswa SMA karena siswa SMA memang telah benar-benar di persiapkan untuk melanjutkan studi ke perguruan tinggi. Hal ini tentunya akan memberikan tantangan tersendiri bagi siswa SMK yang berminat melanjutkan studi ke perguruan tinggi. Agar dapat bersaing dengan siswa SMA, mereka harus memiliki kemauan dan kemampuan yang kuat.

Minat melanjutkan studi ke perguruan tinggi di pengaruhi oleh beberapa faktor yaitu faktor yang berasal dari dalam diri individu (faktor internal) dan faktor yang berasal dari luar individu (faktor eksternal). Faktor internal meliputi : kemauan dan keberhasilan akademik. Kemauan ini antara lain seperti : keinginan untuk memperdalam ilmu pengetahuan dan keterampilan tertentu, dan keinginan untuk mencapai cita-cita tertentu, dan keinginan untuk menyandang gelar kesarjanaan. Sedangkan faktor eksternal meliputi : status sosial ekonomi orang tua dan pengaruh lingkungan.

Faktor ekonomi orang tua memegang peranan penting dalam kelanjutan studi siswa. Siswa yang bersal dari keluarga yang ekonominya cukup, mempunyai kesempatan yang lebih luas untuk mengembangkan kemampuannya dari pada siswa yang berasal dari keluarga yang ekonominya rendah. Seperti yang di ketahui bahwa sebagian besar siswa SMK berasal dari golongan ekonomi menengah ke bawah. Hal ini tidak mengherankan karena orang tua yang ekonominya rendah cenderung menyekolahkan anaknya pada sekolah kejuruan (SMK) karena nanti setelah lulus anak dapat di harapkan segera bekerja sesuai dengan keterampilannya untuk membantu perekonomian keluarga. Dengan keadaan ekonomi orang tua yang rendah, ada yang membuat siswa mengurungkan niatnya untuk melanjutkan studi ke perguruan tinggi, tetapi ada pula yang membuat siswa terus berusaha karena mereka sadar bahwa dengan pendidikan yang tinggi akan dapat menjadi sarana untuk mencapai kemajuan kearah kehidupan yang lebih baik.

Pada diri siswa yang mempunyai minat yang besar untuk terus melanjutkan studinya maka ia akan berusaha untuk mencari jalan agar dapat terus melanjutkan studi ke perguruan tinggi walaupun ia di hadapkan pada kendala utama yang harus di hadapi yaitu keadaan ekonomi keluarga yang kurang mendukung. Siswa akan berusaha mencari cara untuk mengatasi kendala ekonomi antara lain dengan bekerja sampingan agar keinginannya untuk melanjutkan studi ke perguruan tinggi dapat terwujud.

\section{Kajian Literatur}

Minat merupakan salah satu faktor yang ikut menentukan keberhasilan seseorang, baik dalam hal studi, pekerjaan, maupun aktivitas yang lain. Banyak ahli yang mengemukakan pendapatnya tentang minat yang berbeda-beda, namun pada dasarnya semua itu merupakan pendapat yang paling melengkapi satu sama lain. 
Menurut Kartini Kartono (1996: 112) "Minat merupakan momen dari kecenderungan yang terarah secara intensif kepada satu obyek yang di anggap penting". Sedangkan kata "Minat" dalam KBBI (2008: 774) di artikan sebagai "Kecenderungan hati yang tinggi terhadap sesuatu; gairah; keinginan". Hal ini senada dengan pendapat Muhibbin Syah (1995: 136) yang menyatakan bahwa : "Minat (interest) berarti kecenderungan dan kegairahan yang tinggi atau keinginan yang besar terhadap sesuatu". Adanya keinginan yang besar tersebut dengan sendirinya akan mendorong seseorang untuk lebih memusatkan perhatiannya terhadap sesuatu yang di maksud. Individu yang berminat untuk melanjutkan studi ke perguruan tinggi, tentunya akan lebih bergairah dan lebih memusatkan perhatiannya terhadap berbagai informasi yang berhubungan dengan perguruan tinggi.

Selanjutnya menurut James M. Curran and Deborah E. Rosen (2006:135) An attitude is defined as "a psyschological tendency that is expressed by evaluating a particular entity with some degree of favor or disfavor". Dan batasan tersebut dapat di kemukakan bahwa apabila individu telah mempunyai minat terhadap suatu obyek, maka perhatiannya akan dengan sendirinya tertarik kepada obyek tersebut dan cenderung memberikan perhatian yang lebih besar terhadap obyek tersebut. Rasa ketertarikan itu lah yang mendorong seseorang untuk berminat terhadap suatu obyek, sehingga dalam dirinya timbul keinginan dan kemauan untuk memiliki obyek tersebut. Slameto (1995:180) mengartikan minat sebagai berikut : "Minat adalah suatu rasa lebih suka dan rasa keterikatan pada suatu hal atau aktivitas, tanpa ada yang menyuruh. Minat pada dasarnya adalah penerimaan akan suatu hubungan antara diri sendiri dengan sesuatu di luar diri. Semakin kuat atau dekat hubungan tersebut, semakin besar minat".

Dari pendapat tersebut dapat dikatakan bahwa bila seseorang beminat terhadap suatu hal atau aktivitas tersebut di bandingkan orang yang kurang berminat, dan hal ini di lakukan secara otomatis dari dalam dirinya tanpa ada yang menyuruh. Selain itu dengan semakin dekat hubungan antara diri dengan suatu hal atau aktivitas tersebut menyebabkan minat semakin besar pula. Jadi, suatu minat dapat di ekspresikan melalui suatu pertanyaan yang menunujukkan bahwa seseorang lebih menyukai suatu hal daripada lainnya dan dapat pula dimanifestasikan melalui partisipasi dalam suatu aktivitas.

Minat dapat mempresentasikan tindakan-tindakan (represent motives). Minat tidak bisa di golongkan sebagai pembawaan tetapi sifatnya bisa di usahakan, di pelajari dan di kembangkan. Menurut Ibrahim Bafadal (2001:191) menyatakan bahwa : "Minat bisa di kelompokkan sebagai sifat atau sikap (traits or attitude) yang memiliki kecenderungankecenderungan atau tendensi tertentu" : Marksheffel dalam Ibrahim Bafadal (2001:192) menjelaskan minat sebagai berikut : "Summarizing our discussion of interest thus far indicates that (1) interest are not in born but are learned, acquired, and developed; (2) interest are realated to meaning; (3) interest are clesely associated with a person's social and emotional health and (4) interest are in some menner capable of initiating and directing human behavior".

Berdasarkan penjelasan Marksheffel di atas dapat dibuat penjelasan sebagai berikut:

1. Minat bukan hasil pembawaan manusia tetapi dapat di bentuk atau di usahakan, di pelajari, dan di kembangkan.

2. Minat itu bisa di hubungkan untuk maksud-maksud tertentu untuk bertindak.

3. Secara sempit, minat itu diasosiasikan dengan keadaan sosial seseorang dan emosi seseorang.

4. Minat itu biasanya membawa inisiatif dan mengarah kepada kelakuan atau tabiat manusia.

Berdasarkan pendapat tersebut dapat di ambil pengertian bahwa adalah suatu kecenderungan pada diri individu untuk tertarik terhadap suatu obyek karena di rasakan bermanfaat bagi diriya sehingga timbul keinginan dan kemauan untuk mendekati obyek 
tersebut. Dalam hubungannya dengan penelitian ini maka minat melanjutkan studi ke perguruan tinggi adalah suatu kecenderungan pada diri siswa untuk meningkatkan belajarnya melalui lembaga formal yang lebih tinggi dari pendidikan yang telah di selesaikan guna mencapai suatu taraf tertentu yang di kehendaki oleh siswa tersebut.

Elizabeth B. Hurlock (1999:114) menyatakan bahwa "minat memainkan peranan yang penting dalam kehidupan seseorang dan mempunyai dampak yang besar atas perilaku dan sikap". Jadi seseorang yang benar-benar berminat terhadap suatu obyek, akan berpengaruh terhadap sikap dan perilakunya. Siswa yang mempunyai minat terhadap suatu akan berusaha untuk mencapai tujuan tersebut, meskipun banyak hambatan yang harus di hadapi. Siswa yang kurang berminat cenderung menghindari dan menjauhi untuk melakukan sesuatu walaupun di dukung dengan berbagai fasilitas yang menunjang.

Minat yang di miliki oleh seseorang dapat menjadi dasar atau landasan dalam melaksanakan suatu aktivitas sehingga dapat di peroleh hasil yang optinum. Minat berperan dalam mendorong seseorang untuk mencapai tujuannya. Tujuan seseorang akan tercapai kalau motif yang ada dalam dirinya selalu mendorong dan memacunya. Hal ini sesuai dengan pendapat Ngalim Purwanto (1990:65) yang mengatakan bahwa: "Minat mengarahkan perbuatan kepada suatu tujuan dan merupakan dorongan bagi perbuatan itu". Minat dapat menjadi sumber motivasi yang mendorong orang untuk melakukan sesuatu yang sesuai dengan keinginannya.

Besar kecilnya minat turut mempengaruhi dorongan seseorang untuk beraktivitas. Setiap aktivitas yang di kerjakan dengan penuh minat maka dapat diharapkan hasilnya akan lebih baik. Tetapi sebaliknya, aktivitas yang dikerjakan tanpa di sertai minat, maka hasilnya akan kurang optimal. Hal ini berlaku pula untuk studi di perguruan tinggi. Agar studi di perguruan tinggi sukses, maka perlu di sertai minat yang besar.

Dari uraian tersebut dapat di simpulkan bahwa minat mempunyai peranan yang penting antara lain :

1. Sebagai dasar landasan bagi suatu aktivitas untuk mencapai hasil yang optimal.

2. Sebagai sumber motivasi yang mendorong dan memacu seseorang untuk mencapai tujuan yang di harapkan.

Hurlock (1999:116) menyatakan bahwa "semua minat mempunyai dua aspek, yaitu aspek kognitif dan aspek afektif". Untuk lebih jelasnya di bawah ini di uraikan kedua aspek tersebut.

\section{Aspek Kognitif}

Aspek kognitif didasarkan atas konsep yang di kembangkan anak mengenai bidang yang berkaitan dengan minat. Konsep yang membangun aspek ini di dasarkan atas pengalaman pribadi dan apa yang di pelajari di rumah, di sekolah, dan di mayarakat, serta dari berbagai jenis media massa, sehingga rasa ingin tahu mereka dapat terpenuhi.

Aspek ini berkisar pada keuntungan dan kepuasan pribadi yang dapat di peroleh dari minat itu. Jika terbukti bahwa ada kepuasan dan keuntungan, minat mereka tidak saja menetap melainkan juga lebih kuat ketika keuntungan dan kepuasan menjadi nyata.

\section{Aspek Afektif}

Aspek afektif di nyatakan dalam sikap terhadap kegiatan yang di timbulkan minat. Aspek afektif berkembang dari pengalaman pribadi, dan sikap orang yang penting (misalnya orang tua, guru, dan teman sebaya) terhadap kegiatan yang berkaitan dengan minat tersebut, dan dari sikap yang di nyatakan atau tersirat dalam berbagai bentuk media masa terhadap kegiatan itu. Contohnya anak yang mempunyai hubungan yang menyenangkan dengan para guru, biasanya mengembangkan sikap yang positif terhadap sekolah. Karena pengalaman sekolahnya menyenangkan, minat mereka pada sekolah di perkuat. 
Sedangkan menurut Kartini Kartono (1996:112) mengemukakan bahwa : "Minat erat berkaitan dengan kepribadian, dan selalu mengandung unsur afektif/perasaan, kognitif dan kemauan". Dari rumusan tersebut dapat di indentifikasi adanya aspek-aspek minat sebagai berikut:

\section{Afektif atau Perasaan}

Perbuatan atau perilaku kita sehari-hari pada umumnya di sertai oleh afek atau perasaanperasaan tertentu. Banyak orang-orang yang di dalam hidupnya tingkah lakunya terutama di warnai oleh perasaannya, baik perasaan senang atau tidak senang. Aspek afektif ini menyangkut tujuan yang berhubungan dengan perubahan sikap, nilai, perasaan, minat dan mental.

\section{Kognitif}

Pengertian kognitif meliputi aspek-aspek struktur intelek yang di pergunakan untuk mengetahui sesuatu. Pada dasarnya kemampuan kognitif merupakan hasil belajar. Sebagaimana di ketahui bahwa hasil belajar merupakan perpaduan antara faktor pembawaan dan pengaruh lingkungan (faktor dasar dan ajar). Jadi perkembangan kognitif bukan hanya hasil kematangan organisme, bukan pula pengaruh lingkungan saja, melainkan interaksi antara keduanya.

\section{Kemauan}

Menurut Abu Ahmadi (1998:125), "Kemauan adalah dorongan dari dalam secara sadar berdasarkan pertimbangan pikir dan perasaan, serta seluruh pribadi seseorang yang menimbulkan kegiatan yang terarah pada pencapaian tujuan tertentu yang berhubungan dengan kebutuhan hidup pribadinya". Kemauan di sebut juga kekuatan, kehendak untuk memilih dan merealisasikan suatu tujuan. Kekuatan kemauan beraksi apabila di rangsang oleh adanya kebutuhan. Gejala kemauan erat hubungannya dengan adanya suatu tujuan dan merupakan salah satu unsur dari minat karena adanya kemauan mendorong tumbuhnya minat. Hal ini sesuai dengan pendapat Abu Ahmadi (1998:26) bahwa "Kemauan mendorong tumbuhnya minat, mendorong gerak aktivitas ke arah tercapainya tujuan".

Dari uraian di atas, dapat di kemukakan bahwa pada dasarnya tidak ada perbedaan yang mendasar antara aspek minat yang di kemukakan oleh Hurlock dan Kartini Kartono. Jadi secara keseluruhan dapat peneliti simpulkan bahwa ada beberapa aspek yang membangun minat yaitu aspek kognitif dan aspek afektif. Hal ini berarti peneliti sependapat dengan Hurlock. Aspek kognitif merupakan hasil belajar yang dapat berkembang menjadi minat. Sedangkan aspek afektif merupakan bobot emosional konsep yang membangun aspek kognitif minat dan dinyatakan dalam sikap terhadap kegiatan yang ditimbulkan minat.

Menurut Witherington (1999:136), "Bentuk minat dapat dibagi menjadi dua yaitu minat primitif dan minat kultural". Untuk selanjutnya dapat peneliti uraikan sebagai berikut :

1. Minat Primitif (minat logis)

Minat Primitif adalah minat yang timbul dari kebutuhan-kebutuhan jaringan, misalnya makanan, kebebasan, aktivitas lainnya. Minat timbul karena adanya dorongan serta kebutuhan yang di adakan secara langsung dapat memenuhi atau mempertahankan kehidupan. Minat primitif ini di miliki oleh setiap orang, karena pada dasarnya orang mempunyai keinginan untuk memenuhi kebutuhannya, sehingga mau tidak mau seseorang akan memunculkan minat dalam dirinya.

2. Minat kultural (minat sosial)

Minat kultural adalah minat yang berasal dari perbuatan belajar, sehingga dapat dikatakan bahwa minat di peroleh dari pendidikan. Orang yang benar-benar terdidik ditandai oleh 
adanya minat yang benar-benar luas serta benar-benar dalam terhadap hal-hal yang bernilai. Dalam hal ini minat melanjutkan studi merupakan minat kultural karena minat tersebut tidak tumbuh dengan sendirinya tetapi banyak faktor yang turut mempengaruhinya. Melanjutkan studi merupakan suatu hal yang bernilai, bermanfaat atau berguna bagi masa depan seseorang. Minat ini hanya dimiliki oleh orang-orang tertentu yang mempunyai kecenderung untuk belajar, karena orang yang memiliki latar belakang pendidikan mau tidak mau harus memiliki minat untuk kemajuan dirinya.

Sedangkan menurut I.L. Pasaribu dan B. Simanjuntak (1990:52), "Bentuk minat dapat dibedakan menjadi minat aktual dan minat disposisional".

1. Minat Aktual

Adalah minat yang berlaku pada obyek yang ada pada suatu saat dan ruangan yang konkret. Maksudnya adalah bahwa minat seseorang akan muncul dengan tiba-tiba apabila orang tersebut merasa tertarik dengan sesuatu hal tersebut sifatnya nyata.

\section{Minat Disposisional}

Adalah minat yang dasarnya pembawaan dan menjadi ciri sikap hidup seseorang. Minat ini dimiliki oleh seseorang sejak orang tersebut lahir terus berkembang seiring dengan usianya tanpa di bina pun minat ini akan berkembang dengan sendirinya.

Dari uraian di atas, maka dapat dilihat adanya persamaan antara bentuk minat yang kemukakan oleh Witherington dan Pasaribu. Minat primitif memiliki persamaan dengan minat disposisional dimana minat ini bersifat asli dan alami. Sementara itu minat kultural dan minat aktual merupakan minat yang dapat di pengaruhi oleh perubahan suatu keadaan.

Minat pada diri seseorang tidak terjadi secara tiba-tiba melainkan melalui proses. Dengan kata lain minat bukanlah sesuatu yang dimiliki seseorang begitu saja, melainkan merupakan sesuatu yang dapat di pelajari dan di kembangkan. Pada dasarnya minat selalu mengalami perubahan. Sejak kecil minat seseorang itu di pengaruhi oleh keadaan jasmaninya, perasaan dan lingkungannya.

Menurut Oemar Hamalik (1990:97), “Timbulnya minat pada diri seseorang dapat pula di sebabkan oleh pengaruh lingkungannya atau oleh lembaga sosial, seperti : keluarga, kelompok bermain, sekolah, dan sebagainya". Elizabeth B. Hurlock (1994:216) menyatakan bahwa "Minat bergantung pada inteligensi, lingkungan dimana ia hidup, kesempatan untuk mengembangkan minat, minat teman sebaya, status dalam kelompok sosial, kemampuan bawaan, minat keluarga dan banyak faktor lain".

Sedangkan menurut Ruber yang di kutip oleh Muhibbin Syah (1995:136) mengemukakan bahwa : "Minat banyak tergantung pada faktor-faktor internal seperti : pemusatan perhatian, keingintahuan, motivasi, dan kebutuhan". Untuk selanjutnya dapat peneliti jelaskan sebagai berikut :

\section{Pemusatan Perhatian}

Menurut Kartini Kartono, "perhatian itu merupakan reaksi umum dari organisme dan kesadaran yang menyebabkan bertambahnya aktivitas, daya konsentrasi, dan pembatasan kesadaran terhadap satu obyek". (1996:111). Perhatian itu sangat di pengaruhi oleh perasaan dan suasana hati dan di tentukan oleh kemauan. Sesuatu yang dianggap luhur mulia dan indah, akan memikat perhatian. Sebaliknya segala sesuatu yang membosankan, sepele dan terus menerus berlangsung secara otomatis, tidak akan bisa memikat perhatian.

\section{Keingintahuan}

Keingintahuan yang ada pada individu sejalan dengan daya kreativitasnya. Biasanya individu yang mempunyai keingintahuan besar menunjukkan keinginannya pula untuk 
mengetahui lebih banyak tentang dirinya dan juga tentang lingkungannya. Ciri lain adalah bahwa mereka selalu mengadakan eksplorasi terhadap lingkungannya dan rangsangan yang datang padanya untuk dapat di ketahui lebih banyak. Dengan adanya rasa ingin tahu yang besar terhadap obyek tertentu, maka individu akan berminat untuk mengetahui lebih banyak tentang obyek yang menarik minatnya tersebut.

\section{Motivasi}

Motivasi mempunyai hubungan yang sangat erat dengan minat. Motivasi muncul karena ada kebutuhan, begitu juga dengan minat. Sehingga tepatlah kalau minat merupakan alat motivasi yang pokok. Seseorang yang mempunyai motivasi tertentu, akan lebih berminat untuk mencapai tujuan. Jadi dapat di katakan bahwa motivasi menunjukkan suatu keadaan yang menyebabkan seseorang melakukan suatu aktivitas tertentu sebagai pencerminan pelaksanaan minat untuk mencapai tujuan yang di kehendakinya atau mendapat kepuasan dengan perbuatannya.

\section{Kebutuhan}

Kebutuhan merupakan sesuatu hal yang cepat atau lambat harus di penuhi. Seseorang akan berminat terhadap sesuatu hal apabila hal tersebut mempunyai hubungan dengan kepentingan atau kebutuhannya sendiri. Jadi jelas bahwa soal minat akan selalu berkaitan dengan soal kebutuhan atau keinginan, oleh karena itu yang penting bagaimana menciptakan kondisi tertentu agar anak selalu butuh dan ingin terus belajar.

Minat untuk melanjutkan studi tidaklah datang secara otomatis tetapi ada beberapa faktor yang mempengaruhinya. Begitu juga dengan minat untuk melanjutkan studi ke perguruan tinggi pada siswa SMK. Ada beberapa faktor yang perlu di pertimbangkan. Menurut Josef Ilmoe (1984:4), minat terhadap studi lanjut di pengaruhi oleh 2 faktor, yaitu :

1. Faktor Internal, meliputi :

a. Keinginan memperdalam ilmu pengetahuan.

b. Keinginan mencapai status sosial yang baik.

c. Keinginan mengejar karir.

d. Adanya kemauan belajar lebih lanjut.

2. Faktor Eksternal, meliputi :

a. Adanya pengaruh lingkungan

b. Tersedia sarana dan kesempatan belajar

c. Dukungan ekonomi keluarga

d. Keberhasilan studi

Menurut Elizabeth B. Hurlock (1999:37) menyatakan bahwa "Kondisi yang mempengaruhi minat anak pada sekolah yaitu pengalaman dini sekolah, pengaruh orang tua, sikap saudara kandung, sikap teman sebaya, keberhasilan akademik, sikap terhadap pekerjaan, hubungan guru dan murid, dan suasana emosional sekolah".

1. Pengalaman dini sekolah

Minat bergantung pada kesiapan belajar, baik secara fisik maupun mental. Anak yang secara fisik dan intelektual telah siap untuk bersekolah mempunyai sikap yang lebih positif terhadap sekolah di bandingkan anak yang belum siap untuk sekolah. Pengalaman yang menyenangkan pada sekolah dapat menumbuhkan minat yang besar pada diri anak untuk terus belajar. 
2. Pengaruh orang tua

Orang tua mempengaruhi sikap anak terhadap sekolah secara umum dan juga sikap mereka terhadap pentingnya pendidikan, belajar, terhadap berbagai mata pelajaran dan terhadap pada guru.

3. Sikap saudara kandung

Saudara kandung yang lebih besar mempunyai pengaruh yang sama pada sikap anak terhadap sekolah seperti orang tua. Sebaliknya, sikap saudara kandung yang lebih muda relatif tidak penting.

4. Sikap teman sebaya

Minat dan sikap anak terhadap sekolah secara umum sangat diarahkan oleh teman sebaya. Jika teman sebaya kebanyakan lebih memilih kerja daripada sekolah, maka anak akan terpengaruh dan kemudian memutuskan untuk kerja.

5. Penerimaan oleh kelompok teman sebaya

Karena bagian hari-hari sekolah yang di sukai berpusat sekitar kegiatan ekstrakurikuler dengan teman dengan guru dan nilai yang bagus tidak dapat mengimbangi kurangnya penerimaan oleh teman sebaya.

6. Keberhasilan akademik

Sikap anak terhadap sekolah dapat pula tergantung pada nilai keberhasilan akademik. Keberhasilan akademik akan meningkatkan minat anak pada sekolah dan kegagalan akademik dapat mengurangi minat anak pada sekolah.

7. Sikap terhadap pekerjaan

Anak sekolah menengah atas mulai memikirkan masa depan mereka secara bersungguhsungguh. Cita-cita tentang jenis pekerjaan di masa yang akan datang merupakan faktor penting yang mempengaruhi minat dan kebutuhannya untuk belajar. Pada usia remaja telah mulai jelas terbentuknya cita-cita yang ideal untuk menetapkan pola kehidupannya di masa datang, setelah dewasa nanti. Oleh karena itu dapat dikatakan bahwa remaja telah memiliki minat yang jelas terhadap jenis pekerjaan tertentu. Untuk itu remaja secara sadar telah mengetahui pula bahwa untuk mencapai jenis pekerjaan yang di idamkan itu memerlukan sarana pengetahuan dan keterampilan tertentu yang harus di miliki.

8. Hubungan guru dan murid

Banyak atau sedikitnya minat anak terhadap sekolah di pengaruhi sikapnya terhadap guru. Jika anak memiliki hubungan yang baik dengan para guru, maka anak akan mengembangkan sikap yang positif terhadap sekolah.

9. Suasana emosional sekolah

Suasana emosional sekolah di pengaruhi sikap guru dan jenis di siplin yang di gunakan. Suasana emosional sekolah yang menyenangkan dapat meningkatkan minat anak pada sekolah.

Dari pendapat para ahli di atas dapat di simpulkan bahwa beberapa faktor yang mempengaruhi minat untuk melanjutkan studi ke perguruan tinggi yaitu faktor yang berasal dari dalam diri individu (faktor internal) dan faktor yang berasal dari luar individu (faktor eksternal). Faktor internal terdiri dari kemauan dan keberhasilan akademik, sedangkan faktor eksternal terdiri dari status sosial ekonomi orang tua dan terpengaruh lingkungan. 


\section{Faktor Internal}

a. Kemauan

Menurut kamus Bahasa Indonesia Kontemporer (1991:951), "kemauan adalah apa yang di inginkan, keinginan, kehendak". Kartini Kartono berpendapat bahwa "kemauan merupakan dorongan keinginan pada setiap manusia untuk membentuk dan merealisasikan diri, dalam pengertian : mengembangkan segenap bakat dan kemampuannya serta meningkatkan taraf kehidupannnya". Setiap kemauan itu bertalian erat dengan suatu tujuan atau cita-cita tertentu yang ingin di capai. Seorang siswa memiliki kemauan untuk melanjutkan studi karena pada diri siswa tersebut terdapat keinginan seperti : keinginan untuk memperdalam ilmu pengetahuan tertentu, keinginan mencapai status sosial ekonomi yang baik, keinginan mengejar karir dan lain sebagainya.

b. Keberhasilan akademik

Keberhasilan akademik bisa dilihat dari prestasi belajar siswa. Siswa yang memiliki prestasi belajar yang baik, akan mempunyai minat yang lebih besar untuk melanjutkan studi daripada siswa yang berprestasi sedang-sedang saja. Tetapi hal ini tidak dapat dijadikan pedoman. Walaupun siswa memiliki prestasi yang baik dan berminat melanjutkan studi kepeguruan tinggi tetapi apabila sudah terbentur oleh soal biaya, maka siswa tersebut akan mengurungkan niatnya. Sebaliknya, bagi siswa yang berprestasi sedang-sedang saja tetapi keadaan ekonomi keluarganya mendukung, maka siswa tersebut dapat mewujudkan minatnya untuk melanjutkan studi keperguruan tinggi.

2. Faktor eksternal, terdiri atas :

a. Status sosial ekonomi orang tua

Status sosial ekonomi orang tua adalah kedudukan orang tua dalam masyarakat yang dapat ditunjukkan dari pekerjaan, tingkat pendidikan, besarnya penghasilan, fasilitas dan barang-barang berharga. Siswa yang status sosial ekonomi orang tuanya baik atau berkecukupan memiliki kesempatan yang lebih luas untuk mengembangkan kemampuannya dalam hal ini melanjutkan studi dari pada siswa yang keadaan ekonomi keluarganya rendah. Siswa yang orang tuanya berpendidikan tinggi lebih mungkin melanjutkan studinya keperguruan tinggi dari pada siswa yang orangtuanya berpendidikan rendah. Tetapi perlu di ingat bahwa tetap saja ada perkecualian. Tidak semua siswa yang berasal dari keluarga yang ekonominya berkecukupan mau melanjutkan studi ke perguruan tinggi dan sebaliknya banyak siswa yang datang dari keluarga yang kurang berkecukupan mampu melanjutkan studi ke perguruan tinggi. Karena justru dengan keadaan ekonomi keluarga yang rendah akan menjadi cambuk baginya untuk belajar lebih giat dan akhirnya kesuksesan di raihnya.

\section{b. Lingkungan}

Yang di maksud dengan lingkungan adalah segala sesuatu yang ada di sekitar individu di dalam hidupnya. Lingkungan mempunyai pengaruh yang cukup besar terhadap perkembangan anak dalam menuju ke arah kedewasaan. Anak akan berprilaku kurang baik apabila berada pada lingkungan yang kurang baik. Lingkungan dapat di bagi menjadi tiga macam yaitu :

1) Lingkungan Alam : yaitu keadaan tanah, tumbuh tumbuhan, iklim, cuaca, dan lain sebagainya. 
2) Lingkungan Kebudayaan : yaitu suatu lingkungan yang merupakan hasil buatan dan binaan manusia baik material maupun immaterial, seperti : rumah, perlengkapan hidup, hasil teknologi, dan lain sebagainya.

3) Lingkungan Sosial, terdiri atas :

a) Lingkungan Keluarga

Keluarga merupakan lingkungan pertama dan utama bagi anak, oleh karena itu kedudukan keluarga dalam pengembangan kepribadian anak sangatlah dominan. Melalui lingkungan keluarga, anak mengenal dunia sekitarnya dan pola pergaulan hidup yang berlaku sehari-hari. Orang tua, saudara maupun keluarga terdekat lazimnya mencurahkan perhatiannya untuk pendidikan anak agar anak berhasil dalam hidupnya.

b) Lingkungan Sekolah

Sekolah merupakan lembaga pendidikan formal yang mempunyai program yang sistematik dalam melaksanakan bimbingan, pengajaran dan latihan kepada anak (siswa) agar mereka berkembang sesuai dengan pontensinya. Para pendidik di sekolah (guru) berperan dalam hal membimbing anak didiknya agar mempunyai dorongan yang besar untuk menyelesaikan studinya sampai jejang yang tinggi.

c) Lingkungan Masyarakat

Yang di maksud lingkungan masyarakat di sini adalah situasi atau kondisi interaksi sosial dan sosiokultural yang secara pontensial berpengaruh terhadap perkembangan dan kepribadian anak. Lingkungan masyarakat sangat menentukan dan memberi arah serta pengaruh terhadap pembentukan pribadi tiap-tiap individu anak, karena lingkungan masyarakat akan memberikan sumbangan yang sangat berarti dalam diri anak.

Hurlock (1994 : 220) menyatakan bahwa "Besarnya minat remaja terhadap pendidikan sangat dipengaruhi oleh minat mereka pada pekerjaan. Kalau remaja mengharapkan pekerjaan yang menuntut pendidikan tinggi, maka pendidikan akan di anggap sebagai batu loncatan" Hal ini juga berlaku pada diri siswa SMK. Apabila siswa SMK mengharapkan pekerjaan yang baik guna mencapai taraf hidup yang lebih baik dan pekerjaan tersebut menuntut pendidikan tinggi, maka siswa tersebut akan berusaha sekeras mungkin agar dapat melanjutkan studi ke perguruan tinggi. Dengan belajar dan bekerja keras maka keberhasilan akan terwujud.

Pendidikan pada hakekatnya merupakan suatu proses pendewasaan anak didik baik dewasa jasmaniah, rokhaniah maupun sosial. Pendidikan sebagai suatu aktivitas yang merupakan proses tersebut banyak di jumpai problema-problema tersebut dapat menjadi kendala atau penghambat apabila tidak mendapatkan pemecahannya.

Menurut Soemardi Hartoyo (1996:58), Faktor-faktor yang merupakan kendala pendidikan anak adalah :

1. Faktor ekonomi dengan indikator yang divisualisasikan dalam bentuk rendahnya tingkat kehidupan masyarakat dan berbagai perilaku yang bermuara pada masalah ekonomi, yang banyak di pakai alasan tidak menggunakan kesempatan belajar.

2. Faktor sosial budaya dengan indikator yang di proyeksikan dalam bentuk sempitnya cakrawala pandang tentang pendidikan dan kuatnya sosiokultural masyarakat tradisional dalam ikut memberi corak kehidupan masyarakat.

3. Lingkungan sosial yang ditampakkan dalam bentuk kepeloporan dan keteladanan contohnya dari golongan petani yang berhasil dalam pendidikan dan hidupnya.

Soedomo Hadi (2003 : 48) menyatakan bahwa dalam pendidikan banyak di jumpai masalah-masalah yang bisa di tinjau dari beberapa aspek antara lain :

1. Keadaan sosial ekonomi 
Keadaan sosial ekonomi orang tua murid yang tidak mencukupi menyebabkan tersendat sendatnya proses pendidikan anak. Misalnya sulit untuk bisa membeli buku, membayar SPP, uang laboratium, uang transfortasi dan lain sebagainya.

2. Lingkungan sosial

Lingkungan sosial murid yang kadang-kadang juga tidak mendukung bagi berlangsungnya proses belajar yang baik. Seperti kelompok anak-anak yang mempunyai kebiasaan yang tidak menguntungkan bagi proses belajar, kebiasaan hidup yang tidak teratur yang di sebabkan oleh lemahnya kontrol pengawasan dari pihak orang tua.

3. Harapan/cita-cita murid yang kabur di dalam menetapkan hari depan sehingga tidak ada kemantapan bertindak khusus dalam belajar atau bersekolah.

4. Kontrol sosial yang terlalu lemah terhadap tingkah laku anak.

Sementara itu dalam kata sambutan Menteri Pendidikan Nasional RI yang termuat dalam buku yang berjudul Direktori Beasiswa, menyatakan bahwa :

Sejak masa krisis pada pertengahan tahun 1997, pendidikan di tanah air menghadapi berbagai persoalan antara lain peningkatan jumlah putus sekolah, penurunan angka melanjutkan, serta penurunan kualitas pendidikan. Hal ini di sebabkan oleh menurunnya kemampuan terutama pada masyarakat yang kurang mampu dalam membiayai pendidikan anak-anaknya.

Dari pendapat para ahli di atas dapat di simpulkan bahwa faktor yang menjadi kendala siswa dalam menempuh pendidikan adalah keadaan ekonomi orang tua yang rendah dan lingkungan sosial yang kurang mendukung.

\section{Metode Penelitian}

Penelitian ini berjenis deskriptif kuantitatif, yaitu penelitian yang berupaya untuk memberikan gambaran tentang kondisi di dunia nyata dan menjabarkannya lewat serangkaian angka statistik.

Populasi pada penelitian ini adalah seluruh siswa kelas XII jurusan Akuntansi SMK Dharma Putera Banjarmasin sejumlah 30 orang. Karena seluruh siswa kelas tersebut dijadikan subyek penelitian, maka penelitian ini tidak menggunakan sampel.

Penelitian ini berupaya untuk mengukur variabel minat siswa meneruskan ke perguruan tinggi, yang terbagi kedalam 2 dimensi yang masing-masing memiliki 4 indikator:

1. Faktor Internal, meliputi :

a. Keinginan memperdalam ilmu pengetahuan.

b. Keinginan mencapai status sosial yang baik.

c. Keinginan mengejar karir.

d. Adanya kemauan belajar lebih lanjut.

2. Faktor Eksternal, meliputi :

a. Adanya pengaruh lingkungan

b. Tersedia sarana dan kesempatan belajar

c. Dukungan ekonomi keluarga

d. Keberhasilan studi 
Data dikumpulkan menggunakan kuesioner yang disebarkan kepada seluruh responden penelitian. Analisis dilakukan secara kuantitatif dengan cara membuat distribusi frekuensi dari masing-masing jawaban responden. Hasil distribusi frekuensi tersebut akan diurutkan berdasarkan rankingnya untuk melihat faktor yang paling besar dalam menentukan minat siswa untuk meneruskan pendidikannya ke perguruan tinggi. Tempat penelitian yang di gunakan dalam penelitian ini adalah SMK Dharma Putera Banjarmasin yang beralamat di Jl. Komplek Purna Sakti Jalur IV. RT. 30 Banjarmasin-Kalimantan Selatan.

\section{Hasil Penelitian dan Pembahasan}

Data yang telah dikumpulkan pada penelitian ini kemudian dimasukan kedalam tabel untuk direkap dan di analisis. Rekapitulasi dari jawaban responden ditunjukkan pada Tabel 1.

Tabel 1. Rekapitulasi Jawaban Responden

\begin{tabular}{|c|c|c|c|c|c|c|}
\hline No & Indikator & $\begin{array}{l}\text { Sangat Tidak } \\
\text { setuju }\end{array}$ & $\begin{array}{l}\text { Tidak } \\
\text { Setuju }\end{array}$ & $\begin{array}{l}\text { Ragu- } \\
\text { ragu }\end{array}$ & Setuju & $\begin{array}{l}\text { Sangat } \\
\text { Setuju }\end{array}$ \\
\hline \multicolumn{7}{|c|}{ Faktor Internal } \\
\hline 1. & Memperdalam Ilmu & 1 & 1 & 8 & 13 & 7 \\
\hline 2. & Status Sosial yang lebih baik & 1 & 3 & 3 & 13 & 10 \\
\hline 3. & Mengejar Karier & 1 & 0 & 1 & 12 & 16 \\
\hline 4. & $\begin{array}{l}\text { Kemauan Belajar Lebih } \\
\text { Lanjut }\end{array}$ & 1 & 0 & 4 & 20 & 5 \\
\hline \multicolumn{7}{|c|}{ Faktor Eksternal } \\
\hline 1. & Pengaruh Lingkungan & 0 & 3 & 5 & 19 & 3 \\
\hline 2. & $\begin{array}{l}\text { Tersedianya sarana dan } \\
\text { kesempatan belajar }\end{array}$ & 1 & 0 & 8 & 15 & 6 \\
\hline 3. & Dukungan Ekonomi Keluarga & 3 & 2 & 20 & 4 & 1 \\
\hline 4. & Keberhasilan studi & 1 & 2 & 11 & 9 & 7 \\
\hline
\end{tabular}

Tabel 1 menunjukkan rekapitulasi jawaban responden berdasarkan pada 5 pilihan yang sudah disediakan. Hasil penelitian menunjukkan bahwa sebagian besar responden menjawab setuju dan sangat setuju terhadap pertayaan-pertanyaan yang diberikan.

Tabel 2. Deskripsi Variabel

\begin{tabular}{|c|c|c|}
\hline No & Indikator & Rata-Rata \\
\hline \multicolumn{3}{|c|}{ Faktor Internal } \\
\hline 1. & Memperdalam Ilmu & 3,8 \\
\hline 2. & Status Sosial yang lebih baik & 3,93 \\
\hline 3. & Mengejar Karier & 4,4 \\
\hline \multirow[t]{2}{*}{4.} & Kemauan Belajar Lebih Lanjut & 3,93 \\
\hline & Rata-Rata Faktor Internal & 4,02 \\
\hline \multicolumn{3}{|c|}{ Faktor Eksternal } \\
\hline 1. & Pengaruh Lingkungan & 3,73 \\
\hline 2. & Tersedianya sarana dan kesempatan belajar & 3,83 \\
\hline 3. & Dukungan Ekonomi Keluarga & 3,93 \\
\hline \multirow[t]{2}{*}{4.} & Keberhasilan studi & 3,63 \\
\hline & Rata-Rata Faktor Eksternal & 3,78 \\
\hline
\end{tabular}

Berdasarkan pada tabel 2 diketahui bahwa faktor internal dan faktor eksternal samasama berperan kuat dalam membentuk keinginan siswa untuk melanjutkan pendidikannya ke 
perguruan tinggi. Jika dibandingkan, faktor internal memiliki peran yang lebih kuat dibandingkan dengan faktor eksternal yang artinya dapat disimpulkan bahwa rata-rata siswa ingin melanjutkan ke perguruan tinggi karena alasan yang datang dari diri mereka sendiri.

Tabel 3. Ranking Alasan Siswa Ingin Melanjutkan ke Perguruan Tinggi Karena Faktor Internal

\begin{tabular}{clc}
\hline Ranking & \multicolumn{1}{c}{ Indikator } & Skor Rata-Rata \\
\hline 1 & Mengejar Karier & 4,4 \\
\hline 2 & Status Sosial yang Lebih Baik & 3,93 \\
\hline 2 & Kemauan Belajar Lebih Lanjut & 3,93 \\
\hline 3 & Memperdalam Ilmu & 3,8 \\
\hline
\end{tabular}

Berdasarkan pada Tabel 3, alasan utama mengapa siswa ingin melanjutkan Pendidikannya ke perguruan tinggi dari faktor internal adalah karena mengejar karir. Diurutan kedua adalah status sosial dan kemauan untuk belajar lebih lanjut. Di urutan terakhir adalah keinginan untuk memperdalam ilmu.

Tabel 4. Ranking Alasan Siswa Ingin Melanjutkan ke Perguruan Tinggi Karena Faktor Eksternal

\begin{tabular}{clc}
\hline Ranking & \multicolumn{1}{c}{ Indikator } & Skor Rata-Rata \\
\hline 1 & Dukungan Ekonomi Keluarga & 3,93 \\
\hline 2 & Tersedianya sarana dan kesempatan belajar & 3,83 \\
\hline 3 & Pengaruh Lingkungan & 3,73 \\
\hline 4 & Keberhasilan Studi & 3,63 \\
\hline
\end{tabular}

Berdasarkan pada Tabel 4, alasan utama mengapa siswa ingin melanjutkan Pendidikannya ke perguruan tinggi dari faktor eksternal adalah karena dukungan ekonomi keluarga. Diurutan kedua adalah tersedianya sarana dan prasarana untuk belajar dan diuruan ketiga adalah Pengaru dari lingkungan. Di urutan terakhir adalah keberhasilan studi.

Hasil penelitian ini menunjukkan bahwa rata-rata siswa SMK Dharma Putra Banjarmasin ingin melanjutkan pendidikannya ke perguruan tinggi karena alasan yang datang dari diri mereka sendiri, terutama sekali tentang karir. Seperti kita ketahui Bersama, saat ini dunia kerja memberikan persyaratan akademik yang semakin tinggi terhadap para pencari kerja, dimana Pendidikan setingkat SMP maupun SMA sudah semakin sulit untuk mencari pekerjaan yang layak. Hampir semua instansi atau perusahaan mempersyaratkan gelar sarjana kepada para pelamarnya.

Memang pada dasarnya masih banyak pekerjaan yang tidak menuntut Pendidikan yang tinggi. Permasalahannya adalah biasanya pekerjaan-pekerjaan seperti ini memiliki jenjang karier yang tidak jelas, atau bahkan tidak memiliki jenjang karier samasekali. Pekerjaanpekerjaan seperti ini dalam jangka Panjang seringkali membuat frustasi para pekerjanya karen pada dasarnya semua orang menginginkan kehidupan yang terus meningkat seiring dengan perjalanan waktu. Untuk itulah perguruan tinggi semakin diminati karena memberikan akses pada para pencari kerja untuk mendapatkan pekerjaan dengan karir yang baik, yang memungkinkan mereka untuk terus maju dan berkembang menjadi individu yang semakin baik setiap harinya.

Temuan ini juga penting untuk diperhatikan bagi penyelenggara Pendidikan tinggi, dimana yang dicari oleh calon mahasiswa adalah jaminan bahwa dengan kuliah mereka bisa mendapatkan pekerjaan dengan karir yang baik dan terus berkembang. Oleh karena itu, jika ingin diminati oleh calon mahasiswa, pihak perguruan tinggi harus terus memperbaiki kurikulum pembelajarannya agar sesuai dengan kebutuhan di dunia kerja. Kerjasama dengan 
berbagai perusahaan juga sangat dibutuhkan, sehingga proses perkuliahan bisa menjadi sarana yang tepat bagi mahasiswa untuk mempersiapkan diri pada karir yang dijalaninya kelak.

Dari faktor eksternal, faktor yang memiliki peran paling tinggi adalah dukungan ekonomi keluarga. Temuan ini dirasakan wajar mengingat biaya untuk menempuh perguruan tinggi semakin hari semakin mahal. Tanpa adanya dukungan biaya yang mumpuni dari keluarga, berat bagi siswa SMA untuk bisa melanjutkan pendidikannya ke perguruna tinggi. Temuan ini mengingatkan pada para orang tua agar menyisihkan pendapatannya untuk kepentingan Pendidikan yang layak bagi putra-putrinya.

Melalui semangat yang tinggi untuk mengejar karier dan didukung secara finansial oleh keluarga, diharapkan akan semakin banyak siswa SMA/SMK yang melanjutkan pendidikannya ke perguruan tinggi. Jika itu sudah terjadi, diyakini kehidupan sosial ekonomi dari masyarakat di Indonesia akan perlahan-lahan berkembang menjadi lebih baik.

\section{Kesimpulan}

Dapat disimpulkan bahwa minat siswa untuk melanjutkan pendidikannya ke perguruan tinggi lebih besar disebabkan oleh factor yang bersifat internal, terutama sekali keinginan untuk mendapatkan pekerjaan dengan karir yang baik. Kepada pengelola perguruan tinggi, hasil penelitian ini dapat dijadikan alasan pentingnya mengelola kerjasama yang baik dengan berbagai organisasi dan perusahaan untuk memudahkan lulusan perguruan tinggi mencari pekerjaan yang baik

\section{DAFTAR PUSTAKA}

Ahmadi, A. (1998). Psikiologi Umum. Jakarta: Rineka Cipta.

Hadi, S. (1991). Metodologi Research. Yogyakarta: Yayasan Penebit Fakultas Psikologi UGM.

Hadi, S. (2003). Pendidikan Suatu Pengantar. Surakarta: UNS Press.

Hamalik, O. (1990). Pendidikan Tenaga Kerja Nasional. Bandung: Citra Aditya Bakti.

Hurlock, E.B. (1994). Psikologi Perkembangan Suatu Pendekatan Sepanjang Rentang Kehidupan, Alih Bahasa: Istiwidayanti. Jakarta: Erlangga.

James M. Curran, J.M. \& Deborah, E.R. (2006). Student Attitudes Toward College Courses: An Examination of Influence and Intentions. Journal of Marketing Education, 28 (2), 135-148.

Josef Ilmoe. (1984). Motivasi melanjutkan Studi Siswa SMTA Di DIY. Laporan Penelitian. Yogyakarta: FIP IKIP Yogyakarta.

Kamus Besar Bahasa Indonesia. 2008. Jakarta: Balai Pustaka

Kartono, K. (1996). Pengantar Metode Riset Sosial. Bandung: PT Mandar Maju.

Ketetapan MPR RI No IV./MPR/1998-2004. Tentang Garis-Garis Besar Haluan Negara. Surakarta: Penabur Ilmu.

Muhibbin Syah. (1995). Psikologi Pendidikan Suatu Pengantar Baru. Bandung: Remaja Rosdakarya.

Pasaribu, IL \& Simanjuntak. B. (1990). Proses Belajar Mengajar. Bandung : Tarsito.

Purwanto, N. (1990). Psikologi Pendidikan. Bandung: Remaja Rosdakarya.

Slameto. (1995). Belajar dan Faktor-Faktor Yang Mempengaruhinya. Jakarta:

Rineka Cipta.

Sonhaji, A. (1998). Pelaksanaan Pendidikan Sistem Ganda Di Suatu Sekolah Menengah Kejuruan. Forum penelitian Kependidikan.

Undang-Undang Republik Indonesia No. 20 Tahun 2003. Tentang Sistem Pendidikan Nasional. (2004). Semarang: Aneka ilmu.

Witherington. (1994). Psikologi Pendidikan. Jakarta: Rineka Cipta. 